\title{
STUDIES WITH INAGGLUTINABLE ERYTHROCYTE COUNTS. III. KINETICS OF ERYTHROCYTE DESTRUCTION IN HUMAN BEINGS ${ }^{1}$
}

\author{
BY RAYMOND F. SHEETS, CLINTON D. JANNEY, HENRY E. HAMILTON, AND \\ ELMER L. DEGOWIN \\ (From the Departments of Intermal Medicine and Physiology, College of Medicine, State Uni- \\ versity of Iowa, Iowa City, Iowa)
}

(Submitted for publication July 2, 1951; accepted August 13, 1951)

Many investigators (1-27) have recognized that the transfusion of biologically tagged erythrocytes and the subsequent identification and enumeration of the donor's cells in the circulation of the recipient by differential agglutination affords a valuable method of studying either the fate of the donor's abnormal cells in a normal recipient or the disappearance of normal cells in the diseased person. Most studies, however, have merely indicated the time elapsing between transfusion and the disappearance of the last detectable inagglutinable cells from the circulation. A few attempts $(5,9,16,21)$ have been made to analyze the disappearance curves of donor's cells, but these have dealt only with developing equations which fit the curves without any inferences as to the kinetics.

If counts of inagglutinable cells are sufficiently accurate and frequent during an experiment on transfusion survival, the data are susceptible to analysis by well known methods of analytic geometry and calculus so that the kinetics of erythrocyte destruction may be inferred. The present paper deals with such an approach. In employing cell counts from transfusion survival experiments at least two assumptions must be made: 1 ) the total blood volume of the recipient, which serves as the diluent for the donor's cells, is constant or frequently returns to a steady state during the three or four months of the study and, 2) no appreciable loss of tagged red cells occurs from hemorrhage.

\section{METHODS}

Blood transfusion. Erythrocytes were transfused either from diseased patients to normal recipients or from normal subjects to those with disease. All donors belonged to group $O$ and the recipients were either group $A$ or B. Each donor and recipient in a transfusion experiment

1 Supported financially by the Trust Fund of the Department of Internal Medicine. belonged to compatible subtypes in the $\mathrm{Rh}$ system. Approximately $500 \mathrm{ml}$. of the donor's blood were collected in $3.2 \%$ sodium citrate solution $\left(\mathrm{Na}_{3} \mathrm{C}_{6} \mathrm{H}_{8} \mathrm{O}_{7}+2 \mathrm{H}_{2} \mathrm{O}\right)$ and stored at $4^{\circ} \mathrm{C}$. for less than 18 hours before transfusion. Immediately before transfusion the cells were washed once in $0.9 \%$ sodium chloride solution and resuspended in saline solution. The concentration of erythrocytes was estimated by cell counts and the volume of cell suspension was accurately measured. The cell suspension was injected into the vein by gravity. For the first 24 hours after transfusion frequent plasma samples from the recipient were tested for bilirubin (28) and hemochromogens (29) but these pigments were not demonstrated in abnormal amounts. The recipients were permitted to carry on their usual activities during the study; a few were confined in the hospital as patients. When normal donors were employed, their erythrocytes were demonstrated in other experiments to have normal disappearance curves when transfused to normal recipients.

Erythrocyte counts. Hemacytometer counting chambers with the Improved Neubauer ruling were employed for total cell counts whereas chambers with the FuchsRosenthal ruling, $0.1 \mathrm{~mm}$. deep, were found more convenient for counting inagglutinable cells. Dilutions of cells were made with Thoma erythrocyte and leukocyte pipettes. Counting chambers, cover glasses, and pipettes were certified as to accuracy by the National Bureau of Standards. The erythrocytes were suspended in Gower's solution for total cell counts.

Anti-A and anti-B agglutinating sera were collected from human donors of appropriate blood group who had been immunized by repeated injections of the $A$ and $B$ substances of Witebsky, Klendshoj and McNeil, (30). Each lot of serum was divided into small aliquots sufficient for one day's testing. All portions were then frozen and stored at $-5^{\circ} \mathrm{C}$. until required for use. Thus antiserum of constant potency was provided for all tests on the same subject. Blood of the prospective recipient was combined in measured proportions with serial dilutions of the appropriate antiserum and the concentrations of inagglutinable cells determined by counting. The dilution of antiserum producing the lowest inagglutinable cell count was henceforth employed with that recipient. The procedure likewise furnished the blank inagglutinable cell counts for that recipient. No antisera were employed which did not yield a blank inagglutinable cell count of less than 25,000 per mm. 
Inagglutinable cells were counted by a method previously described and evaluated by us (26). Blood from a freely flowing puncture of the ear lobe was drawn to the mark 0.5 in the Thoma leukocyte pipette which was then filled to the mark 11 with $3.2 \%$ dihydric trisodium citrate solution. The contents of the pipette were then expelled into a clean dry serologic test tube whence the blood suspension was drawn into another dry leukocyte pipette to the mark 1.0 to which suitable antiserum was added to the mark 11 . The serum-cell mixture was expelled into a dry clean serologic tube which was centrifuged for one minute at 1,800 revolutions per minute.

TABLE I

Recipient's total red cell counts and inagglutinable cell counts from each of the studies

\begin{tabular}{|c|c|c|c|c|c|c|c|c|c|c|c|c|c|c|}
\hline \multirow{3}{*}{$\begin{array}{l}\text { Days } \\
\text { after } \\
\text { trang- } \\
\text { fusion }\end{array}$} & \multicolumn{2}{|c|}{$\begin{array}{c}\text { Case 1 } \\
\text { Lub. } \\
\text { Figure 2 }\end{array}$} & \multicolumn{2}{|c|}{$\begin{array}{c}\text { Case 2 } \\
\text { Kruk. } \\
\text { Figure } 3\end{array}$} & \multicolumn{2}{|c|}{$\begin{array}{c}\text { Case } 3 \\
\text { Schr. } \\
\text { Figure } 5\end{array}$} & \multicolumn{2}{|c|}{$\begin{array}{c}\text { Case 4 } \\
\text { Dave } \\
\text { Figure } 6\end{array}$} & \multicolumn{2}{|c|}{$\begin{array}{c}\text { Case } 5 \\
\text { Hjel. } \\
\text { Figure } 7\end{array}$} & \multicolumn{4}{|c|}{$\begin{array}{c}\text { Case 6 } \\
\text { Ram. } \\
\text { Figure } 8\end{array}$} \\
\hline & \multirow{2}{*}{$\begin{array}{l}\text { Total } \\
\text { red cell } \\
\text { count }\end{array}$} & \multirow{2}{*}{$\begin{array}{c}\text { Donor's } \\
\text { cell } \\
\text { count }\end{array}$} & \multirow{2}{*}{$\begin{array}{c}\text { Total } \\
\text { red cell } \\
\text { count }\end{array}$} & \multirow{2}{*}{$\begin{array}{c}\text { Donor's } \\
\text { cell } \\
\text { count }\end{array}$} & \multirow{2}{*}{$\begin{array}{l}\text { Total } \\
\text { red cell } \\
\text { count }\end{array}$} & \multirow{2}{*}{$\begin{array}{c}\text { Donor's } \\
\text { cell } \\
\text { count }\end{array}$} & \multirow{2}{*}{$\begin{array}{c}\text { Total } \\
\text { red cell } \\
\text { count }\end{array}$} & \multirow{2}{*}{$\begin{array}{c}\text { Donor's } \\
\text { cell } \\
\text { count }\end{array}$} & \multirow{2}{*}{$\begin{array}{l}\text { Total } \\
\text { red cell } \\
\text { count }\end{array}$} & \multirow{2}{*}{$\begin{array}{c}\text { Donor's } \\
\text { cell } \\
\text { count }\end{array}$} & \multicolumn{2}{|c|}{$\begin{array}{c}\text { Before } \\
\text { splenectomy }\end{array}$} & \multicolumn{2}{|c|}{$\begin{array}{c}\text { After } \\
\text { splenectomy }\end{array}$} \\
\hline & & & & & & & & & & & $\begin{array}{c}\text { Total } \\
\text { red cell } \\
\text { count }\end{array}$ & $\begin{array}{c}\text { Donor's } \\
\text { cell } \\
\text { count }\end{array}$ & $\begin{array}{l}\text { Total } \\
\text { red cell } \\
\text { count }\end{array}$ & $\begin{array}{l}\text { Donor's } \\
\text { cell } \\
\text { count }\end{array}$ \\
\hline days & \multicolumn{2}{|c|}{ 100/mm.3 } & \multicolumn{2}{|c|}{ 100/mm. } & \multicolumn{2}{|c|}{$10 \mathrm{~s} / \mathrm{mm} . \mathrm{s}^{8}$} & \multicolumn{2}{|c|}{$10 \mathrm{~s} / \mathrm{mm}^{2}$} & \multicolumn{2}{|c|}{$100 / \mathrm{mm}^{3}$} & \multicolumn{2}{|c|}{$100 / \mathrm{mm}^{2}$} & \multicolumn{2}{|c|}{ 100/mm. } \\
\hline $\begin{array}{l}0 \\
1 \\
2 \\
3 \\
4 \\
5\end{array}$ & $\begin{array}{l}5.15 \\
4.92 \\
5.08 \\
4.83\end{array}$ & $\begin{array}{l}.468 \\
.410 \\
.511 \\
.422\end{array}$ & 5.94 & 1.084 & $\begin{array}{l}1.40 \\
1.00 \\
.980 \\
1.00 \\
.930 \\
.760\end{array}$ & \begin{tabular}{|l}
.213 \\
.114 \\
.044 \\
.025 \\
.015 \\
.007
\end{tabular} & $\begin{array}{l}2.43 \\
2.52 \\
2.38 \\
2.24\end{array}$ & $\begin{array}{l}.405 \\
.380 \\
\\
.354 \\
.340\end{array}$ & $\begin{array}{l}5.23 \\
4.92 \\
4.95 \\
4.77\end{array}$ & $\begin{array}{l}.260 \\
.240 \\
.236 \\
.207\end{array}$ & $\begin{array}{l}4.00 \\
4.03 \\
4.04 \\
3.89 \\
3.86\end{array}$ & $\begin{array}{l}.670 \\
.650 \\
.637 \\
.619 \\
.585\end{array}$ & 4.37 & .690 \\
\hline $\begin{array}{r}6 \\
7 \\
8 \\
9 \\
10\end{array}$ & $\begin{array}{l}5.13 \\
5.23 \\
5.13 \\
5.31\end{array}$ & $\begin{array}{l}.461 \\
.461 \\
.453 \\
\\
.448\end{array}$ & 5.64 & .993 & .840 & 0 & $\begin{array}{l}2.33 \\
2.20 \\
2.44 \\
2.56 \\
2.68\end{array}$ & $\begin{array}{l}.342 \\
.329 \\
.324 \\
.313 \\
.296\end{array}$ & $\begin{array}{l}4.83 \\
4.64 \\
4.45\end{array}$ & $\begin{array}{l}.205 \\
.192 \\
.181\end{array}$ & $\begin{array}{l}3.94 \\
3.95 \\
3.90 \\
\\
3.92\end{array}$ & $\begin{array}{l}.554 \\
.523 \\
.549 \\
.468\end{array}$ & 4.32 & .665 \\
\hline $\begin{array}{l}11 \\
12 \\
13 \\
14 \\
15\end{array}$ & 4.89 & .434 & & & & & $\begin{array}{l}2.74 \\
2.46 \\
3.02 \\
2.75 \\
2.80\end{array}$ & $\begin{array}{l}.306 \\
.324 \\
.321 \\
.305 \\
.269\end{array}$ & $\begin{array}{l}4.83 \\
4.97 \\
4.84 \\
4.89 \\
4.59\end{array}$ & $\begin{array}{l}.189 \\
.176 \\
.165 \\
.163 \\
.159\end{array}$ & $\begin{array}{l}3.89 \\
3.98 \\
3.98 \\
4.04 \\
3.94\end{array}$ & $\begin{array}{l}.465 \\
.460 \\
.445 \\
.421 \\
.396\end{array}$ & $\begin{array}{c}3.89 \\
.\end{array}$ & .612 \\
\hline $\begin{array}{l}16 \\
17 \\
18 \\
19 \\
20\end{array}$ & 4.65 & .403 & 5.09 & .894 & & & $\begin{array}{l}2.87 \\
2.86 \\
2.94 \\
3.10\end{array}$ & $\begin{array}{l}.280 \\
.263 \\
.280 \\
.260\end{array}$ & $\begin{array}{l}4.23 \\
4.67\end{array}$ & $\begin{array}{l}.156 \\
.163\end{array}$ & $\begin{array}{l}3.74 \\
3.75 \\
3.89 \\
3.97\end{array}$ & $\begin{array}{l}.362 \\
.331 \\
.315 \\
.319\end{array}$ & & \\
\hline $\begin{array}{l}21 \\
22 \\
24 \\
25 \\
26\end{array}$ & 4.87 & .352 & & & & & $\begin{array}{l}2.83 \\
3.09\end{array}$ & $\begin{array}{l}.246 \\
.209\end{array}$ & 3.65 & .126 & $\begin{array}{l}3.96 \\
3.95 \\
3.58 \\
3.70 \\
3.62\end{array}$ & $\begin{array}{l}.307 \\
.296 \\
.253 \\
.244 \\
.245\end{array}$ & & \\
\hline $\begin{array}{l}27 \\
28 \\
29 \\
30 \\
31\end{array}$ & 5.26 & .348 & & & & & 3.32 & .177 & $\begin{array}{l}4.70 \\
4.65\end{array}$ & $\begin{array}{l}.125 \\
.118\end{array}$ & $\begin{array}{l}3.94 \\
3.76 \\
3.56 \\
\\
3.54\end{array}$ & $\begin{array}{l}.230 \\
.208 \\
.194 \\
.179\end{array}$ & & \\
\hline $\begin{array}{l}32 \\
33 \\
34 \\
35 \\
36\end{array}$ & & & 4.99 & .586 & & & & & 4.57 & .105 & $\begin{array}{l}3.63 \\
3.75 \\
3.86 \\
3.55 \\
3.59\end{array}$ & $\begin{array}{l}.173 \\
.167 \\
.157 \\
.146 \\
.143\end{array}$ & 4.43 & .482 \\
\hline $\begin{array}{l}37 \\
38 \\
39 \\
40 \\
41\end{array}$ & & & & & & & 3.42 & .141 & 4.72 & .086 & $\begin{array}{l}3.46 \\
3.58 \\
3.66 \\
3.66\end{array}$ & $\begin{array}{l}.135 \\
.130 \\
.109 \\
.099\end{array}$ & $\begin{array}{l}4.65 \\
4.49\end{array}$ & $\begin{array}{l}.460 \\
.448\end{array}$ \\
\hline
\end{tabular}


The tube was removed from the centrifuge, flicked on the bottom 20 times with the index finger, and recentrifuged three times with additional flicking between each centrifugation. Finally the tube was flicked and gently shaken by hand, the cells permitted to settle for five seconds, and a sample was withdrawn from the supernatant with a capillary pipette and loaded into one side of the counting chamber. A duplicate sample was similarly treated and loaded into the other side of the chamber. All the inagglutinable cells in $9 \mathrm{~mm}^{2}$ on each side of the counting chamber were counted. The concentration of cells was calculated as follows:

Cells per mm. $.^{2}=$ cells in $9 \mathrm{~mm} .^{2} \times \frac{10}{9} \times 22 \times 11$.

The counts from the two pipettes were averaged. When the number of cells in $9 \mathrm{~mm}^{2}$ was less than 1000 , smaller dilutions were used; so that the error due to the Poisson

TABLE I-Continued

\begin{tabular}{|c|c|c|c|c|c|c|c|c|c|c|c|c|c|c|}
\hline \multirow{3}{*}{$\begin{array}{l}\text { Days } \\
\text { after } \\
\text { trans- } \\
\text { fuaion }\end{array}$} & \multicolumn{2}{|c|}{$\begin{array}{c}\text { Case 1 } \\
\text { Lub. } \\
\text { Figure 2 }\end{array}$} & \multicolumn{2}{|c|}{$\begin{array}{c}\text { Case 2 } \\
\text { Kruk. } \\
\text { Figure } 3\end{array}$} & \multicolumn{2}{|c|}{$\begin{array}{c}\text { Case } 3 \\
\text { Schr. } \\
\text { Figure } 5\end{array}$} & \multicolumn{2}{|c|}{$\begin{array}{c}\text { Case } 4 \\
\text { Dav. } \\
\text { Figure } 6\end{array}$} & \multicolumn{2}{|c|}{$\begin{array}{c}\text { Case } 5 \\
\text { Hijel. } \\
\text { Figure 7 }\end{array}$} & \multicolumn{4}{|c|}{$\begin{array}{c}\text { Case 6 } \\
\text { Ram. } \\
\text { Figure } 8\end{array}$} \\
\hline & \multirow{2}{*}{$\begin{array}{c}\text { Total } \\
\text { red cell } \\
\text { count }\end{array}$} & \multirow{2}{*}{$\begin{array}{c}\text { Donor's } \\
\text { cell } \\
\text { count }\end{array}$} & \multirow{2}{*}{$\begin{array}{l}\text { Total } \\
\text { red cell } \\
\text { count }\end{array}$} & \multirow{2}{*}{$\begin{array}{c}\text { Donor's } \\
\text { cell } \\
\text { count }\end{array}$} & \multirow{2}{*}{$\begin{array}{c}\text { Total } \\
\text { red cell } \\
\text { count }\end{array}$} & \multirow{2}{*}{$\begin{array}{c}\text { Donor's } \\
\text { cell } \\
\text { count }\end{array}$} & \multirow{2}{*}{$\begin{array}{c}\text { Total } \\
\text { red cell } \\
\text { count }\end{array}$} & \multirow{2}{*}{$\begin{array}{l}\text { Donor's } \\
\text { cell } \\
\text { count }\end{array}$} & \multirow{2}{*}{$\begin{array}{l}\text { Total } \\
\text { red cell } \\
\text { count }\end{array}$} & \multirow{2}{*}{$\begin{array}{l}\text { Donor's } \\
\text { cell } \\
\text { count }\end{array}$} & \multicolumn{2}{|c|}{$\begin{array}{c}\text { Before } \\
\text { splenectomy }\end{array}$} & \multicolumn{2}{|c|}{$\begin{array}{c}\text { After } \\
\text { splenectomy }\end{array}$} \\
\hline & & & & & & & & & & & $\begin{array}{c}\text { Total } \\
\text { red cell } \\
\text { count }\end{array}$ & $\begin{array}{l}\text { Donor's } \\
\text { cell } \\
\text { count }\end{array}$ & $\begin{array}{l}\text { Total } \\
\text { red cell } \\
\text { count }\end{array}$ & $\begin{array}{l}\text { Donor's } \\
\text { cell } \\
\text { count }\end{array}$ \\
\hline $\begin{array}{r}\text { days } \\
42 \\
43 \\
45 \\
46 \\
47\end{array}$ & \multicolumn{2}{|c|}{$100 / \mathrm{mm} \cdot \mathrm{s}$} & \multicolumn{2}{|c|}{\begin{tabular}{l|l|l}
$100 / \mathrm{mm} .8$ \\
5.04 & .507
\end{tabular}} & \multicolumn{2}{|c|}{$100 / \mathrm{mm}^{2}$} & $\begin{array}{r}10 \% \\
3.65\end{array}$ & .117 & $\begin{array}{c}10 \% / \\
4.74 \\
\\
4.47\end{array}$ & $\begin{array}{l}.078 \\
.064\end{array}$ & $\begin{array}{l}10 \% / n \\
3.54 \\
3.74 \\
3.46 \\
3.66 \\
3.60\end{array}$ & \begin{tabular}{|l}
$m m .8$ \\
.094 \\
.092 \\
.088 \\
.081 \\
.072
\end{tabular} & \multicolumn{2}{|c|}{$100 / m_{m} \cdot 3$} \\
\hline $\begin{array}{l}48 \\
49 \\
50 \\
52 \\
53\end{array}$ & 4.97 & .324 & & & & & 3.85 & .097 & 4.74 & .065 & $\begin{array}{l}3.66 \\
3.69 \\
3.64 \\
3.58 \\
3.63\end{array}$ & $\begin{array}{l}.065 \\
.061 \\
.058 \\
.051 \\
.045\end{array}$ & & \\
\hline $\begin{array}{l}\mathbf{5 4} \\
\mathbf{5 5} \\
56 \\
\mathbf{5 7} \\
\mathbf{5 8}\end{array}$ & & & 5.26 & .284 & & & 4.36 & .088 & $\begin{array}{l}4.72 \\
5.00\end{array}$ & $\begin{array}{r}.059 \\
.058\end{array}$ & $\begin{array}{l}3.69 \\
3.57 \\
3.82 \\
3.66\end{array}$ & $\begin{array}{l}.044 \\
.038 \\
.034 \\
.032\end{array}$ & & \\
\hline $\begin{array}{l}59 \\
60 \\
61 \\
62 \\
63\end{array}$ & & & 5.29 & .207 & & & & & $\begin{array}{l}4.83 \\
4.64 \\
5.12\end{array}$ & $\begin{array}{l}.045 \\
.027 \\
.024\end{array}$ & $\begin{array}{l}3.57 \\
3.43 \\
3.93 \\
3.69 \\
3.71\end{array}$ & $\begin{array}{l}.029 \\
.026 \\
.020 \\
.018 \\
.020\end{array}$ & & \\
\hline $\begin{array}{l}64 \\
65 \\
66 \\
67 \\
68\end{array}$ & & & 5.04 & .188 & & & 4.17 & .053 & $\begin{array}{l}5.01 \\
5.14\end{array}$ & $\begin{array}{l}.022 \\
.022\end{array}$ & $\begin{array}{l}3.67 \\
3.84\end{array}$ & $\begin{array}{l}.018 \\
.014\end{array}$ & & \\
\hline $\begin{array}{l}74 \\
75 \\
76 \\
77\end{array}$ & & & 5.06 & .093 & & & 4.56 & .038 & $\begin{array}{l}4.97 \\
5.53\end{array}$ & $\begin{array}{l}.015 \\
.018\end{array}$ & 3.57 & .011 & $\begin{array}{l}4.45 \\
4.43 \\
4.37\end{array}$ & $\begin{array}{l}.160 \\
.159 \\
.157\end{array}$ \\
\hline $\begin{array}{l}79 \\
81 \\
83 \\
85 \\
90\end{array}$ & 4.82 & .173 & $\begin{array}{l}4.98 \\
4.70 \\
5.02\end{array}$ & $\begin{array}{l}.053 \\
.038 \\
0\end{array}$ & & & & & $\begin{array}{l}5.62 \\
5.44\end{array}$ & $\begin{array}{l}.014 \\
.015\end{array}$ & & & & \\
\hline $\begin{array}{l}102 \\
115 \\
120 \\
125 \\
134\end{array}$ & $\begin{array}{l}5.08 \\
5.28 \\
4.94 \\
4.98 \\
5.85\end{array}$ & $\begin{array}{l}.071 \\
.054 \\
.046 \\
.053 \\
.015\end{array}$ & & & & & & & & & & & 3.97 & .033 \\
\hline
\end{tabular}




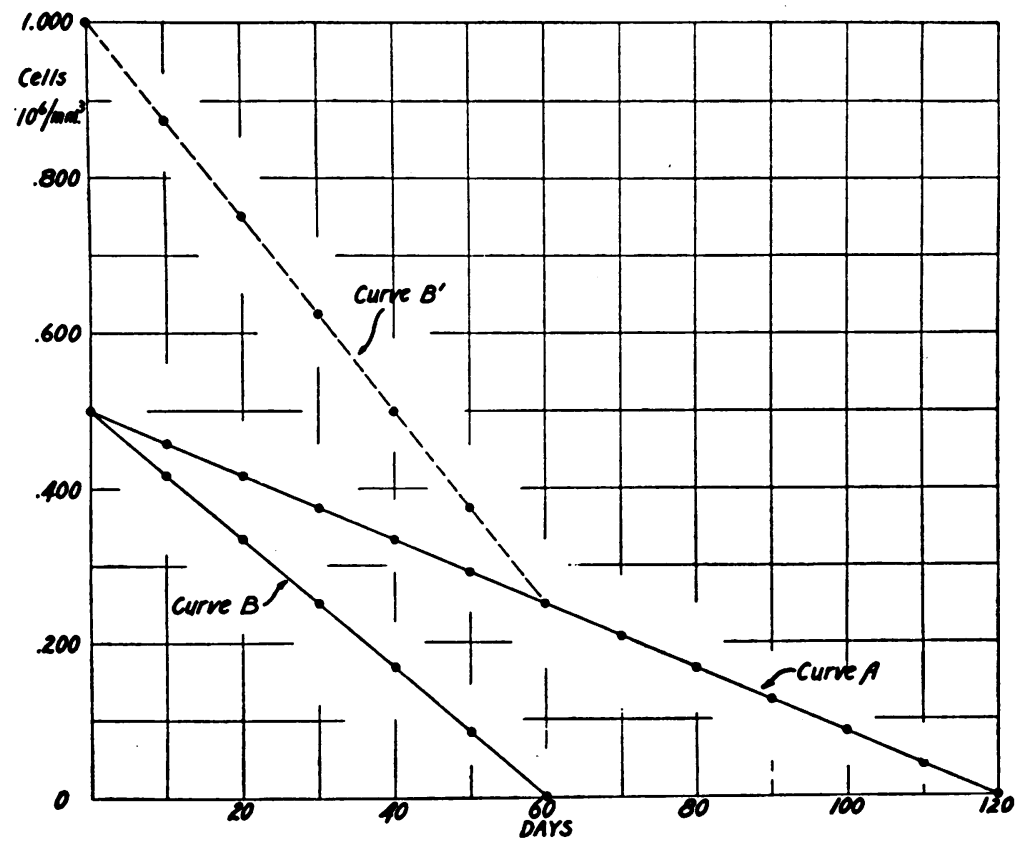

Fig. 1. Disappearance Curves of Transfused Erythrocytes Lost Solely by Aging (Theoretical)

Curve A was constructed to show the situation in which the loss of cells resulted from normal aging. The rectilinear curve, which reaches zero concentration at 120 days, implies that each transfused cell had a life span of precisely 120 days and that the population of the donor's cells at the time of transfusion contained equal numbers of erythrocytes in each age group, all of which lived the remainder of their normal life span in the circulation of the recipient. The same number of transfused cells was therefore lost each day; those lost on the 120th day were presumably less than one day old when taken from the donor's circulation. Curve $B$ is the theoretical curve of disappearance when the donor's cells have a uniform life span of only 60 days. The curve is likewise rectilinear but zero concentration is attained 60 days after transfusion. A disappearance curve similar to B'A can be expected if the transfused cells were a mixture of equal numbers of two populations, one whose cells had a uniform life span of 120 days, the other with a uniform life span of 60 days. The curve $B^{\prime}$ was constructed by adding the values from curve $B$ to those of the first segment of curve A. In practice the curve B'A could be mistaken for a curvilinear curve if insufficient observations were made during the study to show the sharp break at 60 days.

distribution did not become excessively large. The values for the blank inagglutinable cell counts were always subtracted from the observed count. The error ${ }^{2}$ of measurement was estimated to be about $\pm 5 \%$ ( 2 standard deviations on either side of the mean). It took about three months of painstaking practice for technicians to acquire this degree of accuracy.

Plotting. The values for inagglutinable cell counts (Table I) were plotted on Cartesian coordinates with concentrations of cells in millions per $\mathrm{mm}^{2}$ on the ordi-

2 Our evaluation of the errors of counting erythrocytes and inagglutinable cells will be published in detail at a later date. nates (vertical scale) and time in days after transfusion on the abscissae (horizontal scale). The charts were prepared on accurately ruled coordinate paper, nearly one meter square, and the values were plotted to an accuracy of less than one millimeter. The finished chart was then photographed and reduced to the figures in this paper.

\section{AGING AS THE SOLE CAUSE OF DESTRUCTION}

\section{Aging of Normal Erythrocytes}

All workers agree that normal tagged erythrocytes disappear from the circulation of normal re- 
cipients in $120 \pm 15$ days and the plotted values for inagglutinable cell counts describe rectilinear curves as curve $\mathrm{A}$ in Figure 1. The fact that the disappearance curve is a straight line has been interpreted to mean that the life span of each erythrocyte of the donor is approximately 120 days and at any instant the donor's blood is composed of equal numbers of erythrocytes aged one day, two days, etc., up to 120 days. When a volume of freshly collected blood is transfused to a normal recipient, the cells of varied ages live out the remainder of their normal life span in the new environment; those which are already 119 days old survive one day and those which are one day old persist for 119 days in the recipient. When inagglutinable cell counts are made under these conditions, $1 / 120$ of the original number of transfused cells disappears every day, producing the rectilinear curve. This hypothesis is the simplest conceivable to explain the loss. A clinical example follows.

Case 1. Lub., group $\mathrm{A} \mathrm{Rh}_{0}+$, was a male medical student who carried on his usual activities during the study. He was transfused with washed erythrocytes from approximately $500 \mathrm{ml}$. of fresh group $\mathrm{O} \mathrm{Rh}_{0}+$ blood from a normal donor. There was no evidence of immediate hemolysis after transfusion. The data are plotted in Figure 2. The disappearance curve of the donor's cells is rectilinear and the concentration of inagglutinable cells reaches zero at approximately 135 days after transfusion. The day-to-day fluctuations in counts of both total red cells and inagglutinable cells were attributed to changes in plasma volume of the recipient (26).

\section{Delayed Senescence}

A condition is theoretically possible in which the life span of each erythrocyte is increased from 120 days to, say, 150 days. In such a case transfusion survival experiments should yield a rectilinear disappearance curve similar to curve $\mathrm{A}$ in Figure

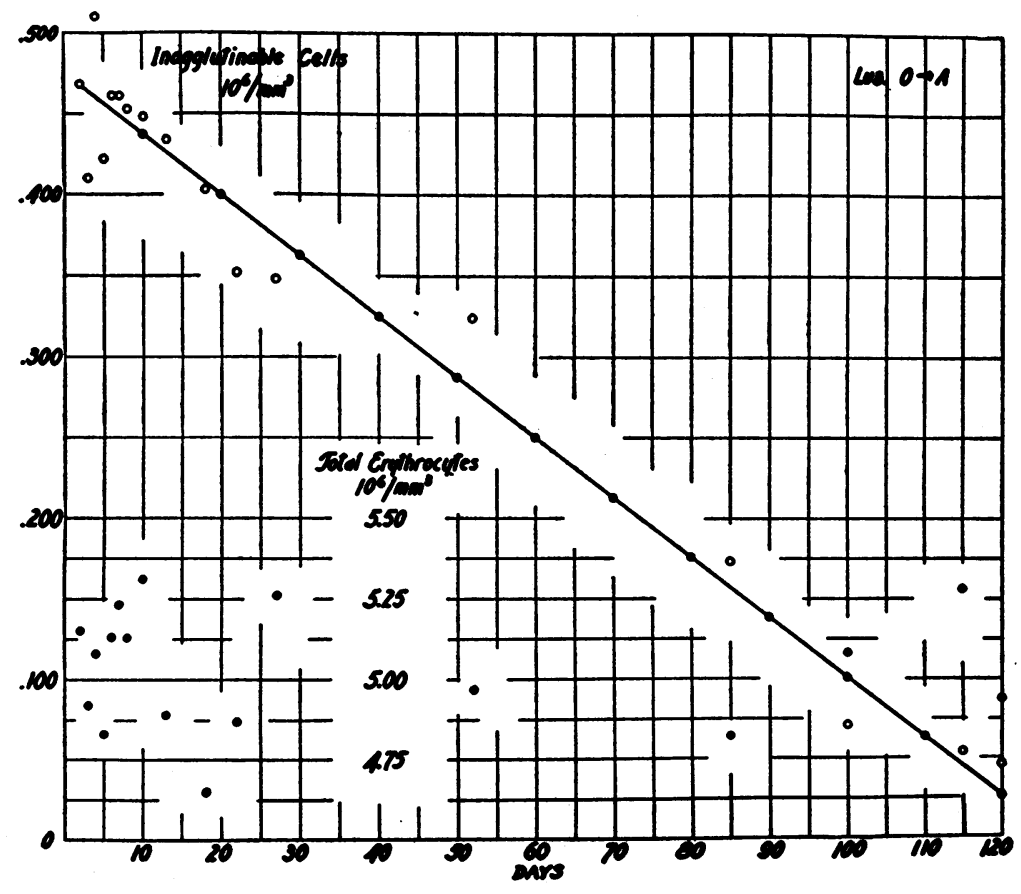

Fig. 2. Disappearance Curve of Transfused Normal Fresh Erythrocytes Lost in Normal Recipient Solely by Aging (Case 1)

A normal recipient (Lub.) of group $A$ was transfused with fresh normal erythrocytes of group $O$ and the donor's cells were subsequently identified and counted by the method of differential agglutination. The observed values for inagglutinable cells are represented by the open circles. The constructed curve is rectilinear and attains zero concentration at approximately 135 days. The values for total erythrocyte counts are plotted as unconnected solid circles on a separate scale in the lower half of the chart. 


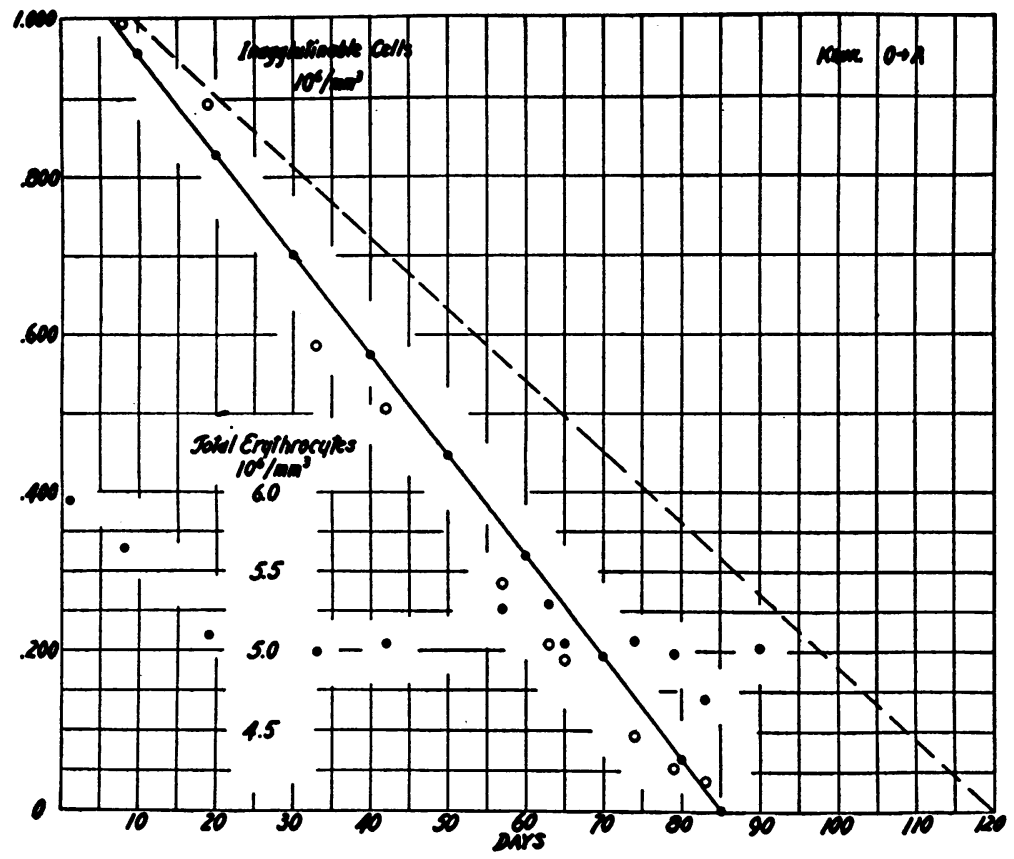

Fig. 3. Disappearance Curve of Transfused Fresh Erythrocytes with Accelerated Senescence in Normal Recipient (Case 2)

The fresh erythrocytes of a donor (M. C.) belonging to group $\mathrm{O}$ and having Cooley's trait (thalassemia minor) were transfused to a normal recipient (Kruk.) belonging to group $A$. The resulting inagglutinable erythrocyte counts are plotted as open circles. The solid line best fits the observed data, is rectilinear, and cuts the horizontal axis at approximately 85 days. The broken rectilinear curve attaining zero concentration at 120 days represents a normal loss rate. The total erythrocyte counts are plotted as unconnected solid circles on a separate scale in the lower half of the chart. In this study it was concluded that these erythrocytes of severe Cooley's trait had an accelerated senescence with a uniform life span of 85 days.

1 in which the inagglutinable cells attain zero concentration in 150 days. No clinical example of this has yet been encountered.

\section{Accelerated Senescence}

If, for example, all the erythrocytes of a cell population have an equal life span of only 60 days, the inagglutinable cell counts in a transfusion survival experiment would describe a rectilinear curve which attains zero concentration at 60 days, as depicted in curve $\mathbf{B}$ of Figure 1. A clinical example of accelerated senescence has been previously described by us (27).

Case 2. M. C., group $\mathrm{O} \mathrm{Rh}_{0}+$, a 20-year-old man had severe Cooley's trait. Fresh washed erythrocytes from him were transfused to a normal one-year-old girl (Kruk.) who belonged to group $A R_{0}+$. The data are plotted in Figure 3 and show the cells from the Cooley's trait disappearing rectilinearly and attaining zero concentration in approximately 85 days.

\section{Two Populations of Cells With Different Life Spans}

If red blood cells with a normal life span are combined with those having an accelerated senescence and the mixture is transfused to a normal recipient, the resulting inagglutinable cell counts should describe a curve of two rectilinear limbs as in curve $B^{\prime} A$, Figure 1. Extrapolation of the limb of lesser slope divides the figure into two triangles which represent the component populations of erythrocytes. The figure was constructed by superposing curve B upon curve A. No clinical example of this situation has yet been encountered but it should be pointed out that such a curve 


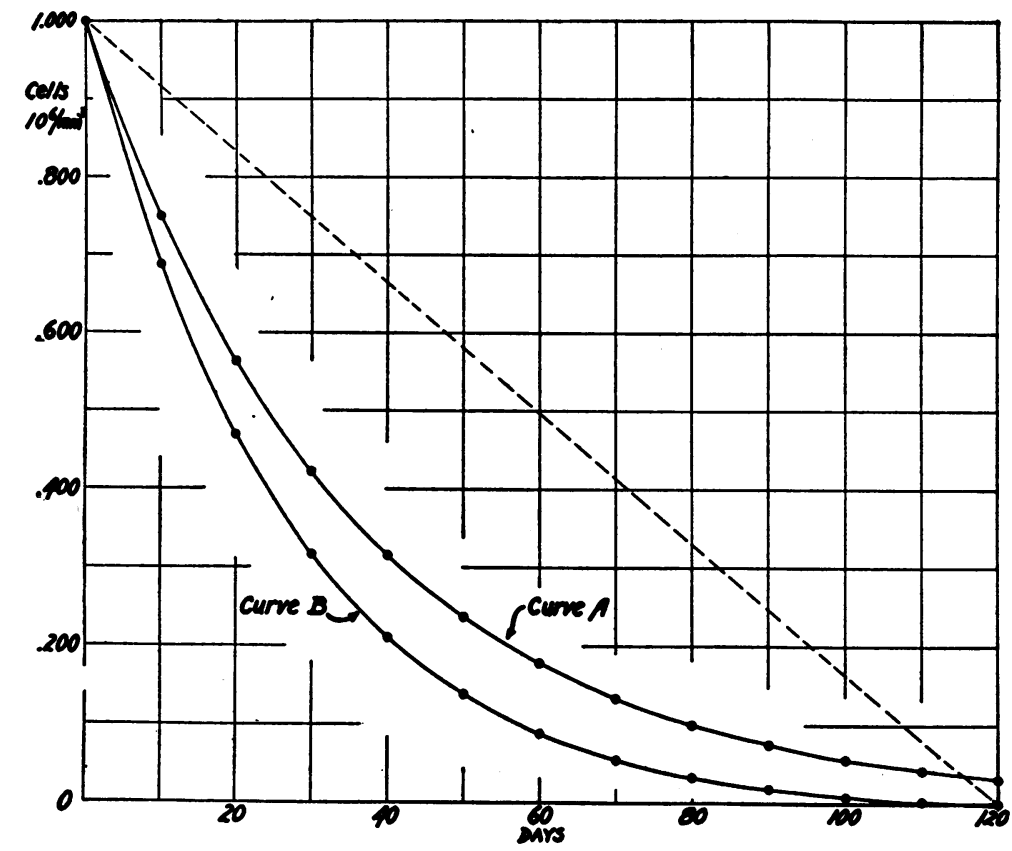

Fig. 4. Disappearance Curves of Transfused Erythrocytes Lost by Random Destruction plus Aging (Theoretical)

Curve A was constructed by assuming that there was no loss of transfused cells by aging but during each 10-day period of the study one-fourth of the cells present at the beginning of the period had been lost by the end of the period by a destructive mechanism acting at random. This produces a pure logarithmic curve which approaches zero but never reaches it. Since all cells are mortal, this hypothetical situation would not be approached if the rate of random destruction were sufficiently slow to permit perceptible losses from aging. Curve $B$ was constructed by assuming the same loss of onefourth of the remaining cells during each 10-day period plus the normal loss of cells from aging. This exhibits a slightly greater rate of total loss than in curve $\mathrm{A}$ and mathematically it attains zero concentration at 120 days when calculated from equation ( 8 ).

might be difficult to distinguish from one of the curvilinear types which shall be described later.

\section{COMBINATION OF NORMAL AGING AND RANDOM DESTRUCTION}

\section{Rapid Random Destruction With Constant Rate Obscuring Loss From Normal Aging}

The simplest kinetic concept by which erythrocytes could be destroyed irrespective of their age involves a mechanism which destroys a certain fraction of the cells available in the first unit of time. The same fraction of the remaining cells disappears during the second time period, and during each succeeding time unit a similar fraction of the remaining cells is lost. This is depicted on
Cartesian coordinates ${ }^{3}$ as a logarithmic or exponential curve. Such a curve approaches zero

${ }^{3}$ In plotting inagglutinable cell counts obtained in a study where random destruction is rapid, the logarithmic character of the curve is better demonstrated if the ordinates and abscissae of the coordinates are nearly equal in length. There are examples of logarithmic curves in the literature which have been treated as rectilinear because a very short survival time was plotted on the usual 120day scale. Examples are also found in the literature of attempts to determine whether survival curves are rectilinear or curvilinear after following the cells for an inadequate length of time. For instance if the study in Figure 7 had been stopped at 40 days and the survival curve extrapolated to zero, it would be interpreted as rectilinear with a survival time of 60 days. We do not believe survival curves can be interpreted accurately unless the inagglutinable cells are followed until near zero concentration. 
concentration but never reaches it because each remainder must be divided into smaller values which are always finite. Curve $A$ in Figure 4 was constructed on the assumption that one-fourth of the remaining cells were destroyed in each 10-day period. Such a curve would only be encountered in transfusion survival experiments when the rate of destruction was so great that the loss from normal aging would be negligible and hence would not distort the pure logarithmic curve appreciably. A clinical example of this was studied.

Case 3. Schr., group $\mathbf{A} \mathrm{Rh}_{0}+$, a 57-year-old man had had lymphatic leukemia for $4 \frac{1}{2}$ years. The spleen and lymph nodes were enlarged. Roentgen irradiation of the spleen had no beneficial effect. Ten blood transfusions, each of $500 \mathrm{ml}$, did not increase the erythrocyte count appreciably. At the time of the experiment the hemoglobin concentration of the blood was $3.7 \mathrm{gm}$. per $100 \mathrm{ml}$.; the erythrocyte count was 960,000 per mm. of which $42.7 \%$ were reticulated; the leukocytes numbered 218,000 per mm., $97 \%$ of which were mature lymphocytes. The red cells were completely hemolyzed in $0.50 \%$ sodium chloride solution. He died one month after the study.

Fresh washed erythrocytes from $500 \mathrm{ml}$. of blood, drawn from a normal donor belonging to group $\mathrm{O} \mathrm{Rh}_{0}+$, were transfused to the patient and the data are plotted in Figure 5. The calculated curve, in the insert, which fits well the observed inagglutinable cell counts, is a logarithmic type in which one-half the remaining cells are lost each day.

In Figure 5 it will be noted that the inagglutinable cells attained zero concentration in six days although the preceding counts fit a logarithmic curve which approaches zero, but never reaches it. This consideration prompts the introduction of the term apparent disappearance time to denote the

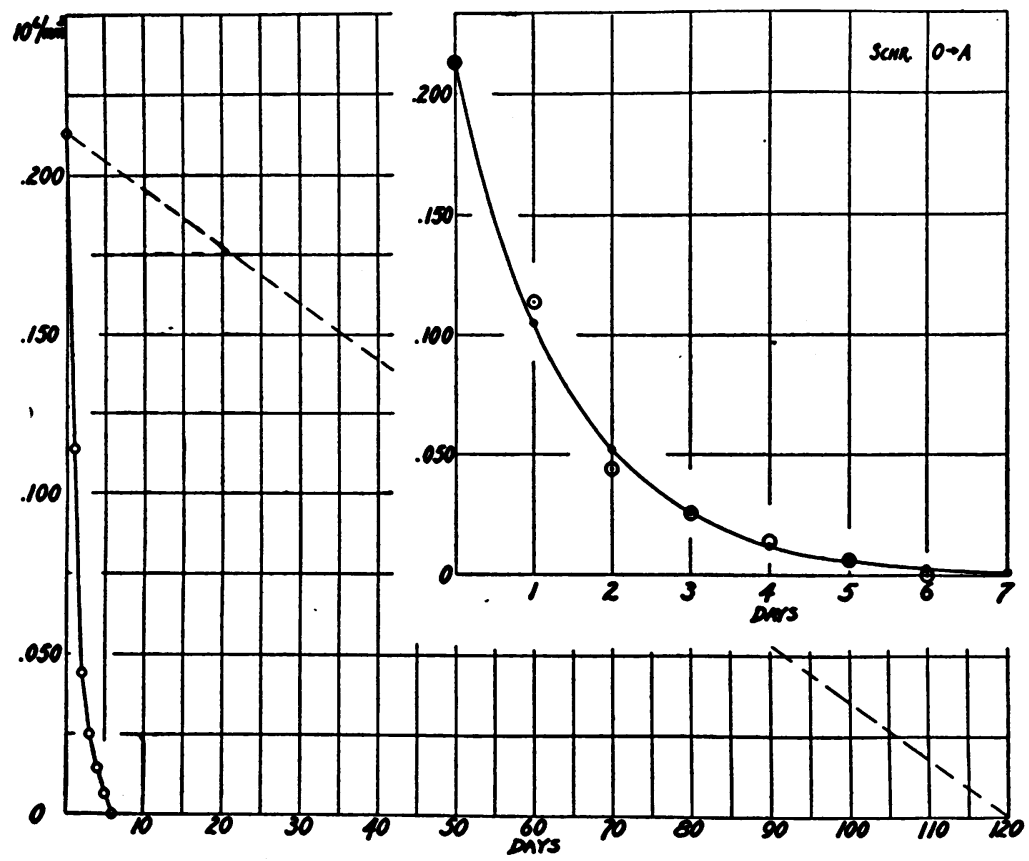

Fig. 5. Disappearance Curve of Transfused Normal Fresh Erythrocytes Lost by Random Destruction Only (Case 3)

Fresh erythrocytes of group $O$ were transfused to a patient with lymphatic leukemia (Schr.) belonging to group $A$. The inagglutinable cell counts (open circles) apparently attained zero concentration at six days. The chart in which the scale of the abscissa is condensed gives no indication of the shape of the disappearance curve. When the time scale is expanded (as in the insert), it is seen that the observed values correspond very closely to a logarithmic curve (connected solid circles) in which half the remaining cells are lost each day. If the rate of random destruction had been slower the observed values would not have fitted a pure logarithmic curve because additional cell loss would have been perceptible from aging. 
point at which the inagglutinable cells become immeasurable by the present laboratory methods.

\section{Slow Random Destruction With Constant Rate Plus Normal Loss from Aging}

When the rate of destruction of erythrocytes by a mechanism acting on cells at random is sufficiently slow, the loss from normal aging assumes a significant role and distorts a disappearance curve which would otherwise be logarithmic. In any unit of time a certain fraction of cells is lost at random as a result of the destructive mechanism. Some of these cells, however, would be lost by aging in any case during that time period. Added to this loss, however, are cells which have reached their life span during this period but have been missed by the random mechanism. Curve $B$ in Figure 4 was constructed on the assumption that one-fourth of the remaining cells were lost at random in each 10-day period (as in curve $A$ of the same figure) but the loss from normal aging has been added. This produces a curve which shows a loss greater than the logarithmic curve $\mathrm{A}$ and mathematically it reaches zero in 120 days.

The double loss of cells can be expressed mathematically. Let $\mathrm{N}_{0}$ be the concentration of inagglutinable cells obtained from a donor whose erythrocyte population is in a steady state (31), that is to say, there are equal numbers of cells of each age from one day to $\mathbf{1 2 0}$ days. If the donor's cells disappear from the circulation of the recipient only because of normal aging, the rate of loss is constant and is proportional to the number of inagglutinable cells originally present. Thus, in the notation of differential calculus,

$$
\frac{\mathrm{dM}}{\mathrm{dt}}=-\mathrm{aN}_{0}
$$

in which $M$ is the concentration of inagglutinable cells remaining at any time $t$, and $a$ is a constant of proportionality.

If some agglutinable cells are destroyed by another factor before their normal life span is attained, the concentration of cells actually present at time $t$ will be less than M. Let the concentration of cells actually present at that time be $\mathrm{N}$. The rate of disappearance of cells from normal aging will then be reduced by the fraction N/M so that it becomes $-(\mathrm{N} / \mathrm{M}) \mathrm{aN}_{0}$. It is to be noted that this expression includes only the cells which disappear because of normal aging. Since another mechanism is simultaneously operating to destroy the donor's cells at random, then the rate of destruction is proportional to the cells present and may be expressed by $-b N$, in which $b$ is a constant of proportionality. The total cells disappearing is the sum of those lost by aging and those destroyed by the random mechanism:

$$
\begin{aligned}
& \frac{d N}{d t}=-\frac{N}{M} a_{0}-b N \\
& \frac{d N}{d t}=-N\left(\frac{a N_{0}}{M}+b\right) .
\end{aligned}
$$

The number $M$ can be expressed as a function of time by integrating equation (1):

$$
M=N_{0}(1-a t) \text {. }
$$

Substituting this value for $M$ in equation (2):

$$
\frac{d N}{d t}=-N\left[\frac{a}{1-a t}+b\right] \text {. }
$$

Integrating equation (4) yields or

$$
\log _{e} \frac{N}{N_{0}(1-a t)}=-b t
$$

$$
N=N_{0}(1-a t) e^{-b t} .
$$

Let $\mathrm{T}$ be the length of time $\mathrm{e}^{4}$ required for all the donor's cells to disappear from the circulation by the normal aging process. Then when $t=T, M=0$. Substituting these values in equation (3) gives $\mathrm{a}=1 / \mathrm{T}$ so that equation (6) may be written

$$
N=N_{0}\left(1-\frac{t}{T}\right) e^{-b t}
$$

Equation (6) can be put into more conventional form by letting $\tau$ be the time in the experiment at which $N=1 / 2 M$. That is to say that $\tau$ is the time after transfusion at which the concentration of donor's cells actually found to be present is half the value expected when the loss is due only to aging. Substituting the value of $M$ from equation (3) in equation (5) gives

$$
\log _{e} \frac{N}{M}=-b t \text {. }
$$

When $\frac{N}{M}=1 / 2, t=\tau$, so that

$$
\begin{aligned}
\log _{e} 1 / 2 & =-b \tau \\
b & =\frac{\log _{e} 2}{\tau} .
\end{aligned}
$$

Now equation (7) becomes

$$
N=N_{0}\left(1-\frac{t}{T}\right) e^{-\frac{\log _{e} 2}{\tau} t}
$$

where

$\mathrm{N}=$ concentration of donor cells at time $\mathrm{t}$ after transfusion,

$\mathbf{N}_{\mathbf{0}}=$ concentration of donor cells at $\mathbf{t}=\mathbf{0}$,

$\mathrm{T}=$ time after transfusion when all the donor's cells would have been lost by senescence, and

$\tau=$ time after transfusion when $\mathrm{N}$ is half the number of cells which would have been present if loss were due only to senescence.

- $T$ is the length of time from transfusion until all normal donor's cells have disappeared from the normal recipient. In our calculations we have assumed 120 days for this value. 
Data acquired in actual erythrocyte survival studies were employed to test the validity of the hypothesis of the kinetics of cell destruction by a random mechanism plus normal aging.

Case 4. Dav., group $A \mathrm{Rh}_{0}+$, was a 77-year-old white man with pernicious anemia. His skin was lemon-yellow and the spleen was enlarged. On admission to the hospital the hemoglobin concentration of the blood was 6.7 $\mathrm{gm}$. per $100 \mathrm{ml}$. and the erythrocytes numbered $1.56 \mathrm{mil}-$ lion per mm." The gastric contents contained no free hydrochloric acid after stimulation with histamine. The bone marrow appeared typical of pernicious anemia. The administration of vitamin $B_{12}$ caused reticulocytosis, increase in concentration of erythrocytes, and subsidence of symptoms.

Normal washed fresh erythrocytes of group $\mathrm{O} \mathrm{Rh}_{0}+$ were transfused to this patient and the observed inagglutinable cell counts were plotted in Figure 6 . On the sixth day of the experiment the administration of vitamin $B_{\mathbf{w}}$ was begun, with a consequent rise in the total erythrocyte counts as depicted on the chart. A curve with an excellent fit for the observed values was constructed by assuming $\tau=40$ days and $T=120$ days in equation $(8)$.
The data are compatible with the hypothesis that normal erythrocytes were destroyed in this patient by a random mechanism with a constant rate in addition to the normal aging process.

In cases 3 and 4 normal erythrocytes were transfused to recipients with disease and the donor's cells were found to be destroyed by a random mechanism presumed to be an abnormal characteristic of the body of the recipient. The following example is presented in which grossly abnormal erythrocytes were apparently destroyed in random fashion, as well as by normal aging, in the body of a normal recipient.

Case 5. Jon., group $\mathrm{O} \mathrm{Rh}_{0}-$, was a 33-year-old woman with proctitis caused by $x$-irradiation of the pelvis for carcinoma of the cervix uteri. The carcinoma was judged to be destroyed. She had received $13 \mathrm{gm}$. of lead acetate in 90 days for diarrhea and had developed typical symptoms of severe lead poisoning. The serum bilirubin was $4.2 \mathrm{mg}$. per $100 \mathrm{ml}$. The hemoglobin concentration of the blood was $8.5 \mathrm{gm}$. per $100 \mathrm{ml}$. and the erythrocytes num-

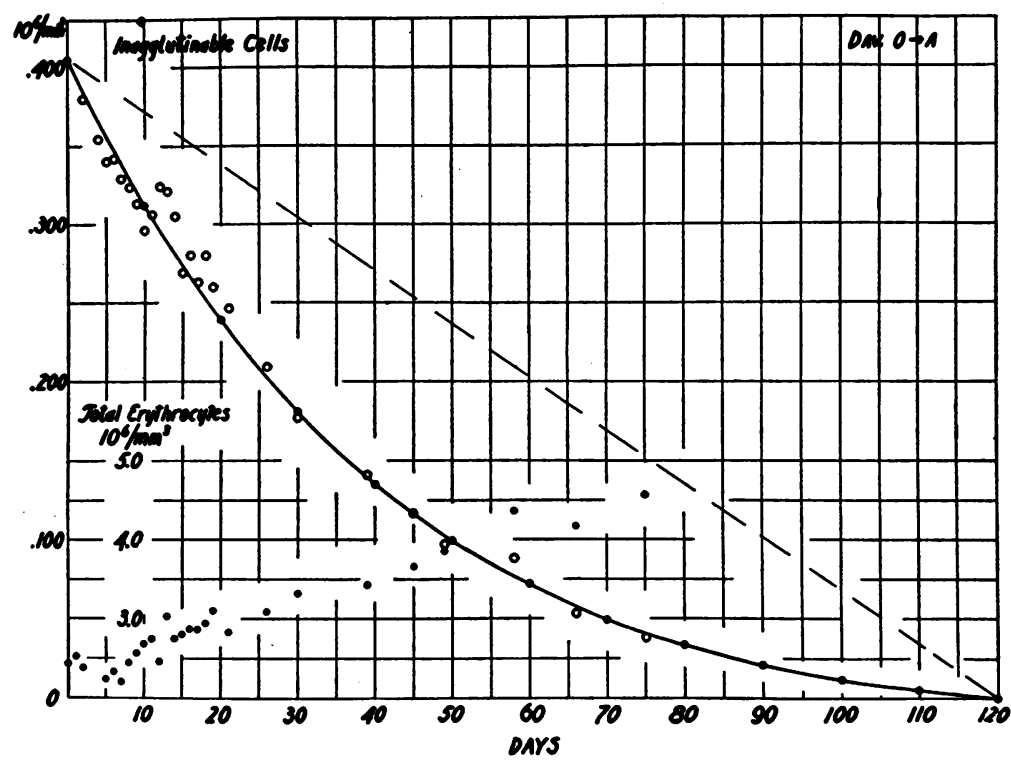

Fig. 6. Disappearance Curve of Transfused normal Fresh Erythrocytes Lost by Random Destruction at a Constant Rate plus Normal Aging (CAse 4)

Fresh erythrocytes from a normal donor belonging to group $O$ were transfused to a patient with pernicious anemia (Dav.) of group A. The resulting inagglutinable cell counts (open circles) fit closely a curve (connected closed circles) constructed from equation (8) using $\tau=40$ days and $T=120$ days. This equation hypothesizes the loss of cells from normal aging plus random destruction at a constant rate. On the sixth day after transfusion the administration of vitamin $B_{1 s}$ was begun, reticulocytosis occurred, and a rapid increase in the total erythrocyte count ensued (see unconnected closed circles on bottom scale). 
bered 3 millions per $\mathrm{mm}^{8}$ of which $3.8 \%$ were reticulated. Stained films of the blood showed heavy stippling of the erythrocytes. Minimal hemolysis of her erythrocytes occurred in $0.38 \%$ sodium chloride solution and hemolysis was complete in a $0.30 \%$ solution. The urinary excretion of lead was $4.7 \mathrm{mg}$. in 24 hours.

Blood was collected from Mrs. Jon., in 3.2\% dihydric trisodium citrate solution, the erythrocytes were washed in $\mathbf{0 . 9 \%}$ sodium chloride solution, and a saline suspension of the cells was transfused to $\mathrm{Hjel}$. The recipient was a healthy man belonging to group $B \mathrm{Rh}_{0}+$. His erythrocyte counts were normal.

The data from the present transfusion experiment are plotted in Figure 7. A curve was constructed from equation (8) assuming $\tau=35$ days and $T=120$ days. This was found to fit the observed data. In this instance the findings are compatible with the hypothesis that the erythrocytes of the donor were in some manner injured by the lead so that they were destroyed at random in an apparently normal recipient, in addition to the loss from the normal aging process.

\section{Slow Random Destruction With Varying Rate Plus Normal Loss from Aging}

In the preceding discussion the rate of the random destructive mechanism was assumed to be constant and the application of equation ( 8 ) to the observed data from several transfusion experiments was compatible with that hypothesis. In another erythrocyte survival study, however, analysis of the data on the inagglutinable cell counts indicated that an assumption of constant rate for the random destruction plus normal aging was not adequate to explain the observed values mathematically.

Case 6. Ram., group A Rho + , a 10-year-old girl, had postnecrotic cirrhosis of the liver from infectious hepatitis. The liver and the spleen were moderately enlarged. There were numerous spider angiomata over the face and thorax. During the period of this study there was

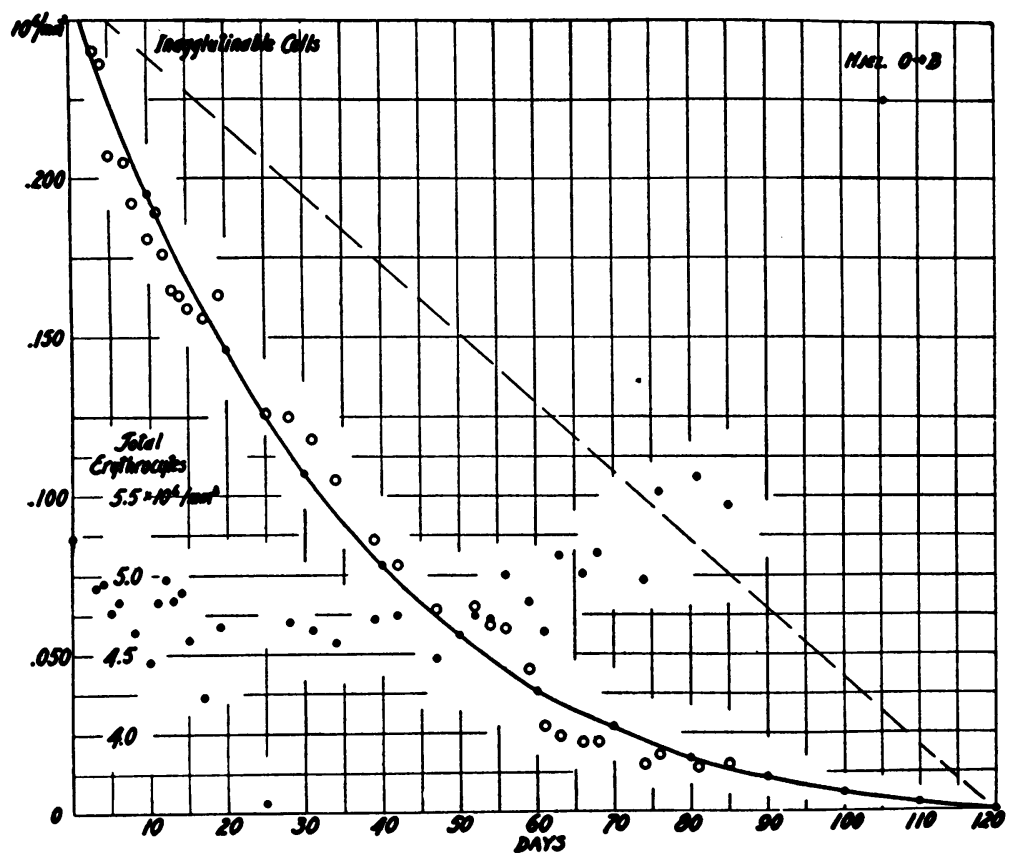

Fig. 7. Disappearance Curve of Fresh Erythrocytes from Donor with Lead Poisoning Lost in Normal Recipient by Random Destruction at Constant Rate plus Aging (Case 5)

Fresh erythrocytes from a donor of group $O$ with severe lead poisoning (Jon.) were transfused to a normal recipient ( $\mathrm{Hjel}$.) belonging to group $\mathrm{B}$. The inagglutinable cell counts (open circles) are well fitted by a curve (connected closed circles) calculated from equation (8) with $\tau=35$ days and $\mathrm{T}=$ 120 days. The equation postulates the loss of cells by random destruction at a constant rate plus normal aging. By the conditions of the experiment it is concluded that the lead in some manner injured the erythrocytes so that normal processes in the circulation of the recipient caused random destruction. 


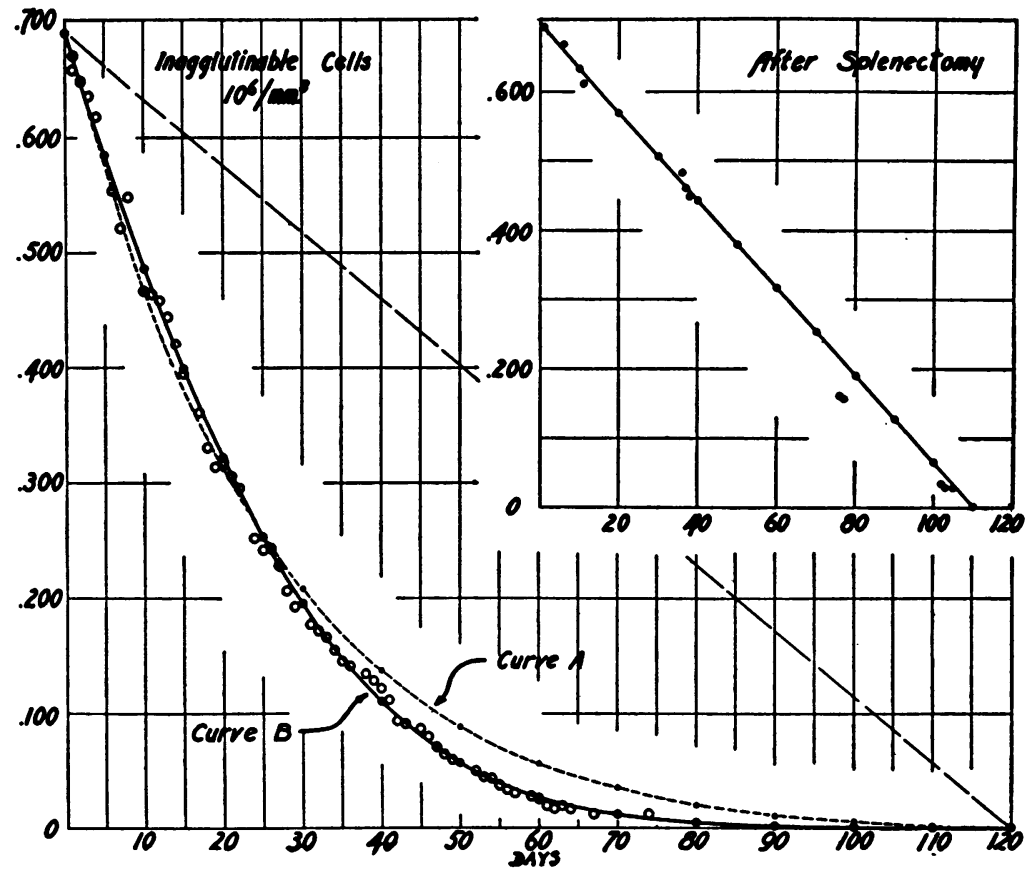

Fig. 8. Disappearance Curve of Transfused Fresh Normal Erythrocytes Lost by Random Destruction with Increasing Rate plus Normal Aging. Abolition of Random Destructive Mechanism after SplenecTOMY (CASE 6)

Fresh group $\mathrm{O}$ erythrocytes from a normal donor were transfused to a patient with postnecrotic cirrhosis of the liver belonging to group $A$. The inagglutinable cell counts (open circles) fitted only the first half of curve $A$, calculated from equation ( 8$)$ in which $\tau=28$ days and $T=120$ days. Nor could any better fit be secured by employing other values in this equation which hypothesizes a constant rate of random destruction plus normal aging. A close fit of the observed data was secured with curve B calculated from equation (14), which assumes loss from normal aging plus random destruction at an increasing rate. The assumption of an increasing rate of cell destruction corresponded well with the clinical observations that the disease was becoming worse. After splenectomy another transfusion of fresh normal erythrocytes survived in the recipient in a normal manner. The inagglutinable cell counts are seen in the insert.

gradual deterioration in her condition although later transient improvement followed splenectomy. The examination of the bone marrow showed hyperplasia of the erythroid and myeloid series. There were megalocytes in the peripheral blood. She was transfused with normal fresh washed erythrocytes of group $\mathrm{O} \mathrm{Rh}_{\mathrm{O}}+$ and the donor's erythrocytes were counted as inagglutinable cells until they were immeasurable. Subsequently splenectomy was performed.

The data from this study are plotted in Figure 8. In attempting to apply equation ( 8 ) it was found that by assuming $\tau=28$ days and $T=120$ days a curve could be constructed which fitted the observed data during the first part of the study, but the distal segment of the curve indicated expected cell counts considerably higher than those actually observed (curve $A$ in Figure 8). We were unable to find a pair of values for $T$ and $\tau$ which would yield a curve that fitted the observed values satisfactorily. Furthermore the apparent increase in the velocity of loss coincided with a worsening in her clinical condition.

With the problem presented by this experiment in mind equations were developed which express, in addition to normal loss from aging, a random destructive mechanism with increasing rate.

In equation (4) $b$ was assumed to be a constant. Now let the assumption be made that $b$ is a function of time, $b(t)$. Then equation (4) becomes

(9)

$$
\frac{d N}{d t}=-N\left[\frac{a}{1-a t}+b(t)\right] \text {. }
$$


Integration gives

$$
\log _{e} \frac{N}{N_{0}(1-a t)}=-\int b(t) d t .
$$

Let it be assumed that $b(t)$ can be expressed in the form:

$$
b(t)=b_{1}+2 b_{2} t
$$

This function represents a random mechanism whose destructiveness increases linearly with time. This is perhaps as simple a form of time variation as is conceivable. Then

$$
\int b(t) d t=b_{1} t+b_{2} t^{2}
$$

Equation (10) now becomes

$$
\log _{e} \frac{N}{N_{0}(1-a t)}=-b_{1} t-b_{2} t^{2}
$$

As before, this can be written in exponential form with $a=1 / T$ :

$$
N=N_{0}\left(1-\frac{t}{T}\right)\left(e^{-b_{1} t}\right)\left(e^{-b_{2} t^{2}}\right) .
$$

This is a kinetic expression in which, in addition to a constant loss of cells from normal aging, there is also a random destruction of cells with an increasing rate. If $b_{2}=0$, this equation reduces to equation $(8)$, which describes the case in which the destructiveness of the random mechanism is constant.

In Case 6, equation (14) was applied to construct curve $B$ in Figure 8 which gives an extremely good fit to the observed data. After completion of the study, the patient's spleen was removed without complications. A few days after operation she was given another transfusion of biologically tagged erythrocytes which showed a linear loss with disappearance at about 120 days (see insert Figure 8). It is presumed that the spleen was the agent responsible for the random destruction of erythrocytes irrespective of age.

One might conceivably formulate many kinds of functions for $b(t)$, instead of that in equation (11). It should be mentioned, however, that, as more constants are introduced, it may become possible to fit the observed curves more closely simply for the reason that there are more constants to juggle; instead of for the reason that there is a correspondence between the theories (leading to the introduction of the constants) and the actual processes which occur.

One Population of Cells Lost Solely by Aging, Another Population Destroyed at Random Plus Aging

If two populations of erythrocytes are transfused to a normal recipient so that one population is lost solely by normal aging and the other population is destroyed by a random mechanism in addition to normal aging, the disappearance curve of the donor's cells will show a proximal limb which is curvilinear and a distal limb which is practically a straight line.

In such a situation one population is represented in equation ( 7 ) when $\mathrm{N}_{0}$ is replaced by $\mathrm{xN}_{0}$ and $\mathrm{b}=0$, where $\mathrm{b}$ is the constant of proportionality and $\mathrm{x}$ is the fraction of transfused cells immune to the random destructive agent. The second population starts with an initial concentration of (1$x) N_{0}$ instead of $N_{0}$ and has a finite value for $b$. If $\mathrm{T}_{1}=\mathrm{T}_{2}=\mathrm{T}$ :

$$
\begin{aligned}
N & =\left[\mathrm{xN}_{0}\left(1-\frac{t}{\mathrm{~T}}\right)\right]+\left[(1-\mathrm{x}) \mathrm{N}_{0}\left(1-\frac{t}{\mathrm{~T}}\right) \mathrm{e}^{-\mathrm{bt}}\right] \\
\mathrm{N} & =\mathrm{N}_{0}\left(1-\frac{\mathrm{t}}{\mathrm{T}}\right)\left[\mathrm{x}+(1-\mathrm{x}) \mathrm{e}^{-\mathrm{bt}}\right] \\
\text { (15) } \mathrm{N} & =\mathrm{N}_{0}\left(1-\frac{\mathrm{t}}{\mathrm{T}}\right)\left[1+\left(\frac{1-\mathrm{x}}{\mathrm{x}}\right) \mathrm{e}^{-\mathrm{bt}}\right](\mathrm{x}) .
\end{aligned}
$$

Let $C=\frac{1-x}{x}$. Solving for $x, x=\frac{1}{C+1}$. Then sub stituting in (15)

(16)

$$
\begin{aligned}
& N=N_{0}\left(1-\frac{t}{T}\right)\left[1+C e^{-b t}\right] \frac{1}{C+1} \\
& N=N_{0}\left(1-\frac{t}{T}\right) \frac{C e^{-b t}+1}{C+1},
\end{aligned}
$$

where

$\mathrm{N}=$ concentration of donor cells at time $\mathrm{t}$ after transfusion,

$\mathrm{N}_{0}=$ concentration of donor cells at $\mathrm{t}=\mathbf{0}$,

$\mathrm{T}=$ time after transfusion when all the donor's cells would have been lost by senescence, and

$\mathbf{t}=$ any day during the period of study.

We have had no example of this combination of circumstances in our own studies. After equation (16) was derived to express the concept of two populations of cells being lost in different ways it was found to be identical with the equation derived empirically by Brown and his associates (21), and Callender, Powell, and Witts (9) to fit their published data on the disappearance of donor's cells after transfusion. Although in their studies the erythrocytes from normal donors were employed, a possible explanation may be that some of the donor's blood had been stored for a few days before transfusion.

\section{SUMMARY}

In our hands the technique of differential agglutination, applied in the enumeration of donor's 
erythrocytes in the circulation of the recipient in erythrocyte survival experiments, has furnished sufficiently accurate data to study the kinetics of red cell destruction.

Studies were made of the destruction of normal erythrocytes in diseased persons and of defective erythrocytes in normal subjects.

The observations and interpretations of others were confirmed that transfused normal erythrocytes completely disappear from the circulation of the recipient in $120 \pm 15$ days and during their life span they are lost in a manner in which their plotted concentrations describe straight lines. This has been assumed to mean that all the erythrocytes in a homogeneous population have approximately the same life span, that a volume of blood freshly collected from a normal donor contains equal amounts of cells varying in age from one day to $120 \pm 15$ days, and that the transfused erythrocytes complete their normal life span in the circulation of the recipient.

A case was reported in which erythrocytes from a subject with severe Cooley's trait completely disappeared from the circulation of a normal recipient in approximately 85 days and the concentrations of donor's cells described a straight line. This was interpreted as evidence that the donor's cells had a uniform life span of only 85 days, an example of accelerated senescence. The possibility was discussed of the existence of clinical examples of delayed senescence.

The hypothesis was proposed that transfused erythrocytes are lost by a destructive mechanism acting at random on the cells, irrespective of age, in addition to the normal aging process. Equations were developed to express the relations when the random destructive mechanism has a constant rate and also when the velocity is increasing during the experiment. The loss of normal erythrocytes from the circulation of a patient with lymphatic leukemia described a pure logarithmic curve which was compatible with the concept of a destructive factor acting at random at a constant rate. The rate was so fast that the loss from normal aging was obscured.

The survival of normal transfused erythrocytes in a patient with pernicious anemia was consistent with the hypothesis that there was an active random destructive mechanism of constant rate in addition to normal aging. A similar explanation was warranted in a study in which the erythrocytes from a patient with severe lead poisoning were lost from the circulation of a normal recipient.

The inagglutinable cells of a normal donor disappeared from the circulation of a patient with anemia and splenomegaly in a manner consistent with the assumption that, in addition to the normal aging process, erythrocytes were being destroyed at random by a mechanism with an increasing rate. After splenectomy a second study with transfusion of normal erythrocytes showed that the cells were lost only by the normal aging process.

An equation was developed to express the relations when a double population of erythrocytes should be transfused, one population lost by normal aging, the other by a random destructive mechanism in addition to normal aging. It was found that this equation coincided with one developed empirically by Brown and his colleagues (21) to fit their observed data.

\section{CONCLUSIONS}

1. Equations were derived for the study of the kinetics of destruction of transfused erythrocytes and applied in human experiments on red blood cell survival.

2. The survival of normal erythrocytes in the circulation of a normal recipient is limited by an aging factor.

3. The survival of defective transfused red cells may be abnormally shortened in a normal recipient because of premature aging.

4. In a diseased recipient the survival of normal transfused erythrocytes may be decreased by a random destructive mechanism acting in addition to the normal aging process.

5. Defective red cells transfused to a normal recipient may be destroyed at random in addition to the normal aging process. Although the disappearance curve of the transfused cells demonstrates that the kinetics of removal are similar to the situation in conclusion 4 , the conditions of this experiment suggest that the defective cells are removed by a normal physiologic process.

\section{REFERENCES}

1. Ashby, W., The determination of length of life of transfused blood corpuscles in man. J. Exper. Med., 1919, 29, 267. 
2. Todd, C., and White, R. G., On the recognition of the individual by hemolytic methods. Proc. Roy. Soc., Series B, 1910, 82, 416.

3. Wearn, J. T., Warren, S., and Ames, O., Length of life of transfused erythrocytes in patients with primary and secondary anemia. Arch. Int. Med., 1922, 29, 527.

4. Mollison, P. L., The survival of transfused erythrocytes, with special reference to cases of acquired haemolytic anaemia. Clin. Sc., 1947, 6, 137.

5. Callender, S. T., Powell, E. O., and Witts, L. J., The life-span of the red cell in man. J. Path. \& Bact., 1945, 57, 129.

6. Young, L. E., Platzer, R. F., and Rafferty, J. A., Differential agglutination of human erythrocytes; evaluation of technique. J. Lab. \& Clin. Med., 1947, 32, 489.

7. Dekkers, H. J. N., The fate of the transfused red blood cells. Acta med. Scandinav., 1939, 99, 587.

8. Loutit, J. F., Discussion on the life and death of the red blood corpuscle. Proc. Roy. Soc. Med., 1946, 39, 757.

9. Callender, S. T., Powell, E. O., and Witts, L. J., Normal red-cell survival in men and women. $\mathrm{J}$. Path. \& Bact., 1947, 59, 519.

10. Mollison, P. L., and Young, I. M:, Survival of the transfused erythrocytes of stored blood. Lancet, 1940, 2, 420.

11. Bushby, S. R. M., Kekwick, A., Marriott, H. L., and Whitby, L. E. H., Survival of stored red cells after transfusion. Lancet, 1940, 2, 414.

12. Denstedt, O. F., Osborne, D. E., Stanfield, H., and Rochlin, I., The survival of preserved erythrocytes after transfusion. Canad. M. A. J., 1943, 48, 477.

13. Ashby, W., Study of transfused blood. II. Blood destruction in pernicious anemia. J. Exper. Med., 1921, 34, 147.

14. Singer, K., King, J. C., and Robin, S., The life span of the megalocyte and the hemolytic syndrome of pernicious anemia. J. Lab. \& Clin. Med., 1948, 33, 1068.

15. Singer, K., Robin, S., King, J. C., and Jefferson, R. N., The life span of the sickle cell and the pathogenesis of sickle cell anemia. J. Lab. \& Clin. Med., 1948, 33, 975.

16. Callender, S. T. E., Nickel, J. F., and Moore, C. V., Sickle cell disease; studied by measuring the survival of transfused red blood cells. J. Lab. \& Clin. Med., 1949, 34, 90.

17. Dacie, J. V., and Mollison, P. L., Survival of normal erythrocytes after transfusion to patients with familial haemolytic anaemia (acholuric jaundice). Lancet, 1943, 1, 550.
18. Dacie, J. V., Transfusion of saline-washed red cells in nocturnal haemoglobinuria (Marchiafava-Micheli disease). Clin. Sc., 1948, 7, 65.

19. Mollison, P. L., The survival of transfused erythrocytes in haemolytic disease of the newborn. Arch. Dis. Childhood, 1943, 18, 161.

20. Young, L. E., and Lawrence, J. S., Atypical hemolytic anemia; observations with particular reference to the use of transfusions in the study of hemolytic mechanisms. Arch. Int. Med., 1946, 77, 151.

21. Brown, G. M., Hayward, O. C., Powell, E. O., and Witts, L. J., The destruction of the transfused erythrocytes in anaemia. J. Path. \& Bact., 1944, $56,81$.

22. Evans, R. S., and Duane, R. T., Acquired hemolytic anemia. I. The relation of the erythrocyte antibody production to activity of the disease; Significance of thromboçytopenia and leukopenia. Blood, $1949,4,1196$.

23. Foy, H., Kondi, A., Rebelo, A., and Soeiro, A., The survival of transfused red cells in blackwater fever circulation and of blackwater red cells in normal circulation (preliminary report). Tr. Roy. Soc. Trop. Med. \& Hyg., 1945, 38, 271.

24. Brown, G. M., Elliott, S. M., and Young, W. A., The haemolytic factor in the anaemia of lymphatic leukaemia. J. Clin. Invest., 1951, 30, 130.

25. Kaplan, E., and Zuelzer, W. W., Erythrocyte survival studies in childhood. II. Studies in Mediterranean anemia. J. Lab. \& Clin. Med., 1950, 36, 517.

26. DeGowin, E. L., Sheets, R. F., and Hamilton, H. E., Studies with inagglutinable erythrocyte counts. I. A method for measurement of net gain or deficit of red cells in the human subject. J. Clin. Invest., 1950, 29, 693.

27. Hamilton, H. E., Sheets, R. F., and DeGowin, E. L., Studies with inagglutinable erythrocyte counts. II. Analysis of the mechanism of Cooley's anemia. J. Clin. Invest., 1950, 29, 714.

28. Malloy, H. T., and Evelyn, K. A., The determination of bilirubin with the photoelectric colorimeter. J. Biol. Chem., 1937, 119, 481.

29. Flink, E. B., and Watson, C. J., A method for quantitative determination of hemoglobin and related heme pigments in feces, urine, and blood plasma. J. Biol. Chem., 1942, 146, 171.

30. Witebsky, E., Klendshoj, N. C., and McNeil, C., Potent typing sera produced by treatment of donors with isolated blood group specific substances. Proc. Soc. Exper. Biol. \& Med., 1944, 55, 167.

31. Ponder, E., Hemolysis and Related Phenomena. Grune \& Stratton, New York, 1948. 